\title{
Dosis dan Waktu Aplikasi Pupuk Kalium pada Pertumbuhan dan Produksi Jagung Manis di BBPP Batangkaluku Kabupaten Gowa Sulawesi Selatan
}

\section{Dose and Time of Potassium Fertilizer Application on Growth and Sweet Corn Production at NATC Batangkaluku Gowa regency of South Sulawesi}

\section{Muhammad Sukma Alfian dan Heni Purnamawati*}

\author{
Departemen Agronomi dan Hortikultura, Fakultas Pertanian, Institut Pertanian Bogor \\ (Bogor Agricultural University), J1. Meranti, Kampus IPB Darmaga, Bogor 16680, Indonesia \\ Telp. \& Faks. 62-251-8629353 e-mail agrohort@apps.ipb.ac.id \\ *Penulis Korespondensi : heni_purnama@yahoo.com
}

Disetujui : 15 Maret 2018 / Published Online 2 Januari 2019

\begin{abstract}
Growth and quality of sweet corn is influenced by environmental factors, one of which is the fertility of the soil. Fertilization is one way that is used to improve soil fertility. The application of fertilizer does not always give effective results because it is influenced by several factors such as dosage, the right way and the right time of application. One of the necessary fertilizer elements is Potassium, which contributes to the synthesis and translocation of carbohydrates; Increase cell wall thickness and stem strength; can increase sugar content; and one of the potassium fertilizer known is $\mathrm{KCl}$. The study was conducted at BBPP Batakuku, Gowa District, South Sulawesi Province This study aims to determine the effect of dosage and application of potassium fertilizer on the growth and production of sweet corn plants. This study used a Randomized Complete Block Design (RCBD) with two factors. The first factor is the dosage of $\mathrm{KCl}$ fertilizer with 4 levels $\left(0 \mathrm{~kg} \mathrm{ha}^{-1}, 50 \mathrm{~kg} \mathrm{ha}, 100 \mathrm{~kg} \mathrm{ha}^{-1}, 150 \mathrm{~kg} \mathrm{ha}\right.$ ) and the second factor the amount of fertilizer application to corn crop with 3 Levels (application at planting, application at planting and 4 WAP, and application at planting, 4 WAP and 7 WAP) were repeated 3 times. The dose of $\mathrm{KCl}$ fertilizer has significant effect on plant height, stem diameter, leaf number, except on plant height 3 WAP, stem diameter $6 \mathrm{WAP}$ and number of leaf aged 3 and $4 \mathrm{WAP}$. The dosage of $\mathrm{KCl}$ fertilizer has significant effect on all variables. The application time has no significant effect on all variables except sweetcorn sweetness level. Interaction has no significant effect on all variables except on plant height aged 6 WAP and sweetness level. All treatments given KCl fertilizers were better results than untreated plants Based on the results of the study, growth and production at $\mathrm{KCl} 50 \mathrm{~kg} \mathrm{ha}^{-1}$ doses were not significantly different from the doses of $100 \mathrm{~kg} \mathrm{ha} \mathrm{g}^{-1}$ and doses of $150 \mathrm{~kg} \mathrm{ha}^{-1}$. The highest sweetness of sweet corn is found in the interaction of dose $150 \mathrm{~kg} \mathrm{ha}{ }^{-1}$ with 3 times application.
\end{abstract}

Keywords: ${ }^{\circ}$ brix, hybrid, level of sweetness

\section{ABSTRAK}

Pertumbuhan dan mutu hasil jagung manis dipengaruhi oleh faktor lingkungan, salah satunya kesuburan tanah. Pemupukan merupakan salah satu cara yang digunakan untuk memperbaiki kesuburan tanah. Aplikasi pupuk dipengaruhi oleh takaran, cara dan waktu pemberian yang tepat. Penelitian dilaksanakan di BBPP Batangkaluku, Kabupaten Gowa, Provinsi Sulawesi Selatan. Penelitian ini bertujuan untuk mengetahui pengaruh dosis dan aplikasi pupuk Kalium terhadap pertumbuhan dan produksi dari tanaman jagung manis. Penelitian ini menggunakan Rancangan Kelompok Lengkap Teracak (RKLT) faktorial dengan dua faktor. Faktor pertama yaitu dosis pupuk $\mathrm{KCl}$ dengan 4 taraf $\left(0 \mathrm{~kg} \mathrm{ha}^{-1}, 50 \mathrm{~kg} \mathrm{ha}^{-1}\right.$, $100 \mathrm{~kg} \mathrm{ha}^{-1}, 150 \mathrm{~kg} \mathrm{ha}^{-1}$ ) dan faktor kedua waktu aplikasi pupuk dengan 3 taraf (aplikasi saat tanam, aplikasi saat tanam dan 4 MST, dan aplikasi saat tanam, 4 MST dan 7 MST) diulang sebanyak 3 kali. Dosis pupuk $\mathrm{KCl}$ berpengaruh nyata dan sangat nyata pada peubah tinggi tanaman, diameter batang, jumlah daun, kecuali pada tinggi tanaman umur 3 MST, diameter batang umur 6 MST dan jumlah daun umur 3 dan 4 MST. Dosis pupuk $\mathrm{KCl}$ berpengaruh nyata dan sangat nyata terhadap semua peubah hasil. Waktu aplikasi tidak berpengaruh nyata pada semua peubah kecuali tingkat kemanisan jagung manis. Interaksi tidak berpengaruh nyata pada semua peubah kecuali pada tinggi umur 6 MST dan tingkat kemanisan. Semua perlakuan yang diberi pupuk $\mathrm{KCl}$ lebih baik hasilnya dibanding tanaman yang tidak mendapat perlakuan Berdasarkan hasil penelitian, pertumbuhan dan produksi pada dosis $\mathrm{KCl} 50 \mathrm{~kg} \mathrm{ha}^{-1}$ tidak berbeda nyata dengan dosis $100 \mathrm{~kg} \mathrm{ha}^{-1}$ dan dosis $150 \mathrm{~kg} \mathrm{ha}^{-1}$. Tingkat kemanisan jagung manis tertinggi didapatkan pada interaksi dosis $150 \mathrm{~kg} \mathrm{ha}^{-1}$ dengan waktu aplikasi 3 kali.

Kata Kunci : ${ }^{\circ}$ brix, hibrida, tingkat kemanisan 


\section{PENDAHULUAN}

Jagung manis (Zea mays saccharata L.) merupakan tanaman dari famili Graminae (rerumputan). Jagung manis merupakan tanaman monokotil dan herbasius yang tumbuh sepanjang tahun (Rubatzky dan Yamaguchi, 1995). Jagung manis merupakan komoditas pertanian yang sangat digemari oleh hampir semua kalangan masyarakat. Rasa jagung manis yang manis, enak dan banyak mengandung karbohidrat, sedikit protein dan lemak (Purwono dan Hartono, 2005). Jagung kaya akan komponen pangan fungsional, termasuk serat pangan yang dibutuhkan tubuh, asam lemak esensial, isoflavon, mineral $(\mathrm{Ca}, \mathrm{Mg}, \mathrm{K}, \mathrm{Na}, \mathrm{P}, \mathrm{Ca}$ dan $\mathrm{Fe}$ ), antosianin, betakaroten (provitamin A), komposisi asam amino esensial, dan lainnya (Suarni dan Yasin, 2015).

Produksi jagung manis saat ini mencapai peningkatan volume ekspor jagung manis pada tahun 2014 sebesar 20056 ton dan pada tahun 2015 meningkat menjadi 78963 ton (BPS, 2015) serta permintaan jagung manis yang mencapai 11.5 ton per hari pada tahun 2011 (Syukur dan Rifianto, 2013). Sulawesi Selatan merupakan salah satu sentra penghasil tanaman jagung. Masyarakat di Provinsi Sulawesi Selatan banyak memanfaatkan jagung manis sebagai salah satu bahan pangan dalam konsumsi makanan harian. Berdasarkan data yang diperoleh dari Badan Pusat Statistik Sulawesi Selatan Kabupaten Gowa memiliki luas lahan dan produksi jagung ke-2 terbesar di Provinsi Sulawesi selatan dengan luas lahan 39997 ha dan produksi 213443 ton (BPS SulSel, 2013).

Seiring dengan kebutuhan yang semakin meningkat maka diperlukan teknik budidaya jagung manis yang tepat agar diperoleh kualitas dan kuantitas produksi yang lebih baik. Penggunaan benih unggul bermutu mutlak diperlukan untuk meningkatkan produktivitas jagung manis. Benih unggul jagung manis dihasilkan melalui kegiatan pemuliaan tanaman. Hasil kegiatan pemuliaan tanaman jagung manis berupa varietas unggul hibrida dan bersari bebas (Syukur dan Rifianto, 2013). Varietas hibrida dibuat untuk mengambil munculnya kombinasi yang baik dari tetua-tetua yang dipakai. Keturunan persilangan langsung dua tetua yang berbeda latar belakang genetiknya dapat menunjukkan penampilan fisik yang lebih kuat dan lebih memiliki potensi hasil yang melebihi kedua tetuanya. Gejala ini dikenal sebagai heterosis dan merupakan dasar bagi produksi berbagai kultivar hibrida, seperti jagung, padi, kelapa sawit, kakao, tanaman sayuran seperti tomat, mentimun, dan cabai (Joe dan Mae, 2005).

Menurut Harjadi (1989), pertumbuhan dan mutu hasil jagung manis diduga dipengaruhi oleh faktor lingkungan kesuburan tanah. Pada prinsipnya pemupukan dilakukan secara berimbang sesuai kebutuhan tanaman dengan mempertimbangkan kemampuan tanah menyediakan hara secara alami, keberlanjutan sistem produksi dan keuntungan yang memadai bagi petani (Sirappa dan Razak, 2010).

Kalium berperan penting dalam pertumbuhan tanaman terutama disaat masa pematangan tanaman karena mempengaruhi fotosintesis dalam pembentukan klorofil, pengisian biji dan esensial dalampembentukan karbohidrat (Janick et al., 1974). Salah satu pupuk kalium yang dikenal adalah $\mathrm{KCl}$. Pupuk $\mathrm{KCl}$ yang dikenal selama ini sebagian besar merupakan hasil tambang (Marsono dan Sigit, 2001).

Kalium terdapat di dalam tanaman dalam kation $\mathrm{k}^{+}$berperan penting dalam respirasi dan fotosintesis. Kalium juga dapat meningkatkan kandungan gula (Taiz dan Zeiger, 2002). Kalium sangat penting bagi pertumbuhan dan perkembangan jagung. Sekitar 25\% kalium terdapat di dalam biji jagung setelah dipanen dan selebihnya terdapat pada batang dan tongkol. Hal ini sejalan dengan hasil penelitian bahwa tanaman muda belum terlalu banyak membutuhkan kalium, tetapi kebutuhan akan cepat menanjak terutama pada saat menjelang keluarnya malai (Tim Penulis PS, 2002).

Penelitian ini bertujuan untuk mengetahui pengaruh dosis dan waktu aplikasi pupuk Kalium terhadap pertumbuhan dan produksi dari tanaman jagung manis.

\section{BAHAN DAN METODE}

Penelitian dilaksanakan pada bulan Agustus sampai dengan November 2016 di Kebun Percobaan Balai Besar Pelatihan Pertanian (BBPP) Batangkaluku, jalan Malino Km. 03, Sungguminasa, Kabupaten Gowa, Provinsi Sulawesi Selatan pada ketinggian 70 mdpl.

Bahan tanaman yang digunakan adalah benih jagung manis Bonanza F1. Pupuk olah tanah yang di gunakan adalah pupuk kandang $\left(5000 \mathrm{~kg} \mathrm{ha}^{-1}\right)$ dan pupuk Dolomit (1000 $\left.\mathrm{kgha}^{-1}\right)$. Pupuk dasar yang digunakan adalah Urea $(300 \mathrm{~kg}$ $\mathrm{ha}^{-1}$ ) dan SP-36 (200 $\left.\mathrm{kg} \mathrm{ha}^{-1}\right)$. Pupuk $\mathrm{KCl}$ digunakan dengan berbagai macam dosis yaitu 0 $\mathrm{kg} \mathrm{ha}^{-1}, 50 \mathrm{~kg} \mathrm{ha}^{-1}, 100 \mathrm{~kg} \mathrm{ha}^{-1}, 150 \mathrm{~kg} \mathrm{ha}^{-1}$ dengan 3 macam aplikasi (1 kali aplikasi, 2 kali aplikasi, 3 kali aplikasi). Dosis $0 \mathrm{~kg} \mathrm{ha}^{-1}$ sebagai kontrol, baik pada 1, 2, dan 3 kali aplikasi. 
Insektisida bahan aktif karbofuran dan profenofos $2 \mathrm{ml} \mathrm{l}^{-1}$. Fungisida bahan aktif mankozeb $2 \mathrm{~g} \mathrm{l}^{-1}$. Alat yang digunakan dalam penelitian adalah cangkul, hand traktor, jangka sorong, tugal, meteran, ajir, tali rafia, timbangan, papan label, refraktometer, dan alat tulis.

Penelitian ini menggunakan Rancangan Kelompok Lengkap Teracak (RKLT) faktorial dengan dua faktor. Faktor pertama yaitu dosis pupuk $\mathrm{KCl}$ dengan 4 taraf $\left(0 \mathrm{~kg} \mathrm{ha}^{-1}, 50 \mathrm{~kg} \mathrm{ha}^{-1}\right.$, $100 \mathrm{~kg} \mathrm{ha}^{-1}, 150 \mathrm{~kg} \mathrm{ha}^{-1}$ ) dan faktor kedua yaitu jumlah aplikasi pupuk terhadap tanaman jagung dengan 3 taraf (aplikasi saat tanam, aplikasi saat tanam dan 4 MST, dan aplikasi saat tanam, 4 MST dan 7 MST). Terdapat 12 kombinasi perlakuan dengan masing-masing terdiri dari 3 ulangan, sehingga terdapat 36 satuan percobaan. Setiap petak percobaan diambil 10 tanaman sebagai tanaman contoh. Jumlah total tanaman contoh sebanyak 360 sebagai satuan pengamatan.

Data yang diperoleh dianalisis menggunakan uji $\mathrm{F}$ pada taraf nyata 5\%. Jika uji nilai $\mathrm{F}$ berpengaruh nyata maka nilai tengah diuji lanjut dengan uji jarak berganda Duncan (Duncan Multiple Range Test/DMRT) pada taraf nyata 5\% (Mattjik dan Sumertajaya, 2013). Pengolahan data menggunakan software SAS 9.0. Interaksi antara dosis dan aplikasi dapat dilihat pada Tabel 1.

Penanaman dilakukan dengan jarak tanam $70 \mathrm{~cm} \times 20 \mathrm{~cm}$ menggunakan tugal. Benih ditanam sebanyak 1 benih tiap lubang tanam dan diberi insektisida bahan aktif karbofuran. Setiap petakan percobaan terdapat 5 baris dan pada tiap baris terdapat 10 lubang tanam. Jumlah tanaman tiap petak sebanyak 50. Secara keseluruhan, jumlah tanaman percobaan sebanyak 1800 tanaman.

Tabel 1. Dosis dan waktu aplikasi pupuk

\begin{tabular}{|c|c|c|c|c|c|}
\hline \multicolumn{6}{|c|}{ Dosis $\left(\mathrm{kg} \mathrm{ha}^{-1}\right)$ dan Waktu Aplikasi } \\
\hline \multicolumn{2}{|c|}{ Jenis Pupuk } & $\begin{array}{c}2 \text { Minggu Sebelum } \\
\text { Tanam }\end{array}$ & Saat Tanam & $4 \mathrm{MST}$ & $7 \mathrm{MST}$ \\
\hline \multicolumn{2}{|l|}{ 1. Kompos } & 5000 & - & - & - \\
\hline \multicolumn{2}{|l|}{ 2. Dolomit } & 1000 & - & - & - \\
\hline \multicolumn{2}{|l|}{ 3. Urea } & - & 150 & 150 & - \\
\hline \multicolumn{2}{|l|}{ 4. SP-36 } & - & 200 & - & - \\
\hline \multicolumn{2}{|l|}{ 5. Kalium (0) } & - & - & - & - \\
\hline \multirow[t]{3}{*}{ Kalium (50) } & A1 & - & 50 & - & - \\
\hline & A2 & - & 25 & 25 & - \\
\hline & A3 & - & 16.8 & 16.6 & 16.6 \\
\hline \multirow[t]{3}{*}{ Kalium (100) } & A1 & - & 100 & - & - \\
\hline & A2 & - & 50 & 50 & - \\
\hline & A3 & - & 33.4 & 33.3 & 33.3 \\
\hline \multirow[t]{3}{*}{ Kalium (150) } & A1 & - & 150 & - & - \\
\hline & A2 & - & 75 & 75 & - \\
\hline & A3 & - & 50 & 50 & 50 \\
\hline
\end{tabular}

Keterangan : $\mathrm{A}=$ waktu aplikasi
Pemeliharaan tanaman meliputi penyulaman, pengendalian gulma, penyiraman, pengendalian hama dan penyakit, dan pembumbunan. Penyulaman dilakukan pada 1 MST dengan tanaman jagung manis yang sudah disemai dengan tujuan agar umur tanaman seragam. Pengendalian gulma dilakukan secara manual. Pengendalian gulma dilakukan sampai jagung berumur 6 MST. Penyiraman dilakukan intensif pada fase pertumbuhan awal dan dilakukan secara berkala. Pengendalian hama dilakukan dengan insektisida dengan bahan aktif karbofuran dan profenofos $2 \mathrm{ml} \mathrm{l}^{-1}$ dilakukan intensif selama 3-5 MST. Pembumbunan dilakukan pada saat tanaman jagung manis berumur 4 dan 6 MST. populasi tanaman berbunga, peubah yang diamati meliputi tinggi tanaman, diameter batang dan jumlah daun yang dihitung dari 2 MST sampai dengan 6 MST. Pengamatan pada saat panen meliputi panjang tongkol, diameter tongkol, bobot tongkol berkelobot, bobot tongkol tanpa kelobot, jumlah baris biji, dan ${ }^{\circ}$ brix jagung manis.

\section{HASIL DAN PEMBAHASAN}

Percobaan dilakukan di lahan penelitian Balai Besar Pelatihan Pertanian (BBPP), Batangkaluku, Gowa pada bulan Agustus November 2016. Menurut data BMKG (Badan Meteorologi Klimatologi dan Geofisika) tahun 2016, curah hujan kumulatif pada bulan agustus hingga November 2016 di Sulawesi Selatan adalah $5 \mathrm{~mm}, 66 \mathrm{~mm}, 317 \mathrm{~mm}$, dan $222 \mathrm{~mm}$ per bulan. Sebaran hari hujan $(\mathrm{HH})$ pada bulan
Pengamatan dilakukan sebelum 50\% 
Agustus-November 2016 yaitu $1 \mathrm{HH}, 15 \mathrm{HH}$, $24 \mathrm{HH}, 22 \mathrm{HH}$. Lahan penelitian di BBPP Batangkaluku berjenis alluvial, dengan ketinggian lokasi $70 \mathrm{mdpl}$. Kandungan yang terdapat pada tanah pada saat sebelum tanam menurut pengujian PUTK, memberikan rekmendasi pemberian pupuk: unsur kalium tergolong sedang $\left(75 \mathrm{~kg}^{-} \mathrm{ha}^{-}\right.$ $\left.{ }^{1}\right)$; fosfor rendah $\left(250 \mathrm{~kg} \mathrm{ha}^{-1}\right)$; C organik rendah $\left(2\right.$ ton ha $\left.{ }^{-1}\right)$ dan $\mathrm{pH}$ antara $5.5-6.0$.

Jumlah tanaman jagung manis yang tumbuh sempurna berjumlah 1744 tanaman dan yang menghasilkan tongkol berisi berjumlah 1724 tanaman. Presentase tanaman yang tumbuh sebesar $96.89 \%$ dari total tanaman yang ditanam. OPT (Organisme Pengganggu Tanaman) yang teridentifikasi pada penelitian ini antara lain ulat grayak (spodoptera sp.), dan ulat penggerek tongkol (Helicoverpa armigera). Penyakit yang menyerang tanaman jagung manis adalah karat daun (Puccinia polysora). Panen tanaman jagung manis pada umur 72 HST. Tongkol jagung dipanen dengan cara dipetik beserta kelobotnya, kemudian ditandai sesuai perlakuan dan pengukuran secara berurutan mulai dari bobot tongkol dengan kelobot, bobot tongkol tanpa kelobot, jumlah baris biji, panjang tongkol dan diameter tongkol. Rekapitulasi hasil uji $\mathrm{F}$ dapat dilihat pada Tabel 2.
Peubah tinggi tanaman didapatkan dosis pupuk $\mathrm{KCl}$ berpengaruh sangat nyata pada 2 MST dan 6 MST. Dosis pupuk $\mathrm{KCl}$ berpengaruh nyata pada $4 \mathrm{MST}$ dan $5 \mathrm{MST}$. Dosis pupuk $\mathrm{KCl}$ tidak berpengaruh nyata pada tinggi tanaman umur 3 MST. Faktor waktu aplikasi tidak berpengaruh nyata pada peubah tinggi tanaman. Faktor interaksi tidak berpengaruh nyata pada semua minggu kecuali pada minggu ke-6, faktor interaksi berpengaruh sangat nyata.

Pada peubah diameter didapatkan dosis pupuk $\mathrm{KCl}$ berpengaruh sangat nyata pada 2-5 MST (Minggu Setelah Tanam), tetapi pada 6 MST faktor dosis tidak berpengaruh nyata. Faktor waktu aplikasi dan interaksi antara dosis dengan waktu aplikasi tidak berpengaruh nyata terhadap pertambahan diameter batang tanaman jagung manis.

Pada peubah jumlah daun tanaman jagung manis didapatkan dosis pupuk $\mathrm{KCl}$ berpengaruh sangat nyata pada 6 MST. Dosis pupuk $\mathrm{KCl}$ berpengaruh nyata pada 2 MST dan 5 MST. Dosis pupuk $\mathrm{KCl}$ tidak berpengaruh nyata terhadap jumlah daun tanaman umur 3 MST dan 4 MST. Faktor waktu aplikasi dan interaksi antara dosis dengan waktu aplikasi tidak berpengaruh nyata terhadap pertambahan jumlah daun terbuka tanaman jagung manis.

Tabel 2. Rekapitulasi hasil sidik ragam (Uji F) pengaruh dosis pupuk $\mathrm{KCl}$ waktu aplikasi, dan interaksi keduanya terhadap pertumbuhan dan produksi jagung manis Zea mays.

\begin{tabular}{|c|c|c|c|c|c|}
\hline \multicolumn{2}{|c|}{ Peubah Pengamatan } & Dosis & Waktu Aplikasi & Dosis*Waktu Aplikasi & KK \\
\hline Tinggi & $2 \mathrm{MST}$ & $* *$ & $\operatorname{tn}$ & $\operatorname{tn}$ & 13.88 \\
\hline Tinggi & $3 \mathrm{MST}$ & $\operatorname{tn}$ & $\operatorname{tn}$ & $\operatorname{tn}$ & 21.78 \\
\hline Tinggi & $4 \mathrm{MST}$ & $*$ & tn & $\operatorname{tn}$ & 9.17 \\
\hline Tinggi & $5 \mathrm{MST}$ & $*$ & $\operatorname{tn}$ & $\operatorname{tn}$ & 8.93 \\
\hline Tinggi & $6 \mathrm{MST}$ & $* *$ & $\operatorname{tn}$ & $* *$ & 4.09 \\
\hline Diameter & $2 \mathrm{MST}$ & $* *$ & $\operatorname{tn}$ & $\operatorname{tn}$ & 19.35 \\
\hline Diameter & $3 \mathrm{MST}$ & $* *$ & tn & tn & 15.27 \\
\hline Diameter & $4 \mathrm{MST}$ & $* *$ & th & $\operatorname{tn}$ & 11.86 \\
\hline Diameter & $5 \mathrm{MST}$ & $* *$ & tn & $\operatorname{tn}$ & 7.98 \\
\hline Diameter & $6 \mathrm{MST}$ & $\operatorname{tn}$ & $\operatorname{tn}$ & $\operatorname{tn}$ & 10.36 \\
\hline Jumlah Daun & $2 \mathrm{MST}$ & $*$ & $\operatorname{tn}$ & $\operatorname{tn}$ & 9.15 \\
\hline Jumlah Daun & $3 \mathrm{MST}$ & tn & tn & $\operatorname{tn}$ & 10.13 \\
\hline Jumlah Daun & $4 \mathrm{MST}$ & tn & tn & $\operatorname{tn}$ & 7.21 \\
\hline Jumlah Daun & $5 \mathrm{MST}$ & $*$ & $\operatorname{tn}$ & $\operatorname{tn}$ & 2.65 \\
\hline Jumlah Daun & $6 \mathrm{MST}$ & $* *$ & tn & tn & 2.36 \\
\hline \multicolumn{2}{|c|}{ Bobot Tongkol dengan Kelobot } & $*$ & tn & $\operatorname{tn}$ & 8.55 \\
\hline \multicolumn{2}{|c|}{ Bobot Tongkol tanpa Kelobot } & $* *$ & $\operatorname{tn}$ & $\operatorname{tn}$ & 7.28 \\
\hline \multicolumn{2}{|c|}{ Panjang Tongkol } & $* *$ & $\operatorname{tn}$ & $\operatorname{tn}$ & 5.61 \\
\hline \multicolumn{2}{|c|}{ Diameter Tongkol } & $* *$ & tn & $\operatorname{tn}$ & 4.28 \\
\hline \multicolumn{2}{|c|}{ Jumlah Baris Biji } & $* *$ & $\operatorname{tn}$ & $\operatorname{tn}$ & 2.82 \\
\hline \multicolumn{2}{|c|}{ Derajat ${ }^{\circ}$ Brix } & ** & $* *$ & $* *$ & 2.32 \\
\hline \multicolumn{2}{|l|}{ Produktivitas } & $*$ & th & $\operatorname{tn}$ & 8.29 \\
\hline
\end{tabular}

Keterangan : $\operatorname{tn}=$ Tidak berbeda nyata pada uji $\mathrm{F}$ pada $\alpha 5 \% ; *=$ Berbeda nyata pada uji $\mathrm{F}$ pada $\alpha 5 \%$; $* *$ Berbeda sangat nyata pada uji F pada $\alpha 1 \%$; KK = Koefisien Keragaman 
Peubah hasil menunjukkan faktor dosis pupuk $\mathrm{KCl}$ berpengaruh nyata dan sangat nyata terhadap semua peubah hasil. Faktor waktu aplikasi tidak berpengaruh nyata pada semua peubah hasil produksi kecuali pada tingkat kemanisan, dimana waktu aplikasi berpengaruh sangat nyata. Faktor interaksi tidak berpengaruh nyata pada semua peubah hasil produksi kecuali pada tingkat kemanisan.

\section{Pertumbuhan Tanaman Jagung Manis}

Pada percobaan ini, perlakuan waktu aplikasi tidak berpengaruh nyata terhadap tinggi tanaman jagung manis. Dosis pupuk $\mathrm{KCl}$ berpengaruh sangat nyata terhadap tinggi tanaman jagung manis pada 2 MST dan 6 MST. Dosis pupuk $\mathrm{KCl}$ berpengaruh nyata terhadap tinggi tanaman jagung manis pada 4 MST dan 5 MST. Dosis tidak berpengaruh nyata pada 3 MST. Data pertumbuhan tinggi tanaman jagung manis akibat perlakuan dosis $\mathrm{KCl}$ dapat dilihat pada Tabel 3.

Berdasarkan Tabel 3 terlihat pertambahan tinggi tanaman dipengaruhi oleh pemberian pupuk K. Tanaman yang tidak mendapatkan perlakuan pupuk $\mathrm{K}$ mempunyai tinggi tanaman yang paling rendah.

Tabel 3. Pengaruh dosis pupuk $\mathrm{KCl}$ terhadap pertumbuhan tinggi jagung manis

\begin{tabular}{lrrrr}
\hline \multirow{2}{*}{ Dosis $\left(\mathrm{kg} \mathrm{ha}^{-1}\right)$} & \multicolumn{4}{c}{ Tinggi Tanaman $(\mathrm{cm})$} \\
\cline { 2 - 5 } & $2 \mathrm{MST}$ & $4 \mathrm{MST}$ & $5 \mathrm{MST}$ & $6 \mathrm{MST}$ \\
\hline 0 & $13.03 \mathrm{~b}$ & $48.98 \mathrm{~b}$ & $99.42 \mathrm{~b}$ & $184.75 \mathrm{c}$ \\
50 & $17.79 \mathrm{a}$ & $55.59 \mathrm{a}$ & $112.63 \mathrm{a}$ & $200.18 \mathrm{a}$ \\
100 & $17.96 \mathrm{a}$ & $52.46 \mathrm{ab}$ & $110.32 \mathrm{a}$ & $192.44 \mathrm{bc}$ \\
150 & $17.39 \mathrm{a}$ & $54.70 \mathrm{a}$ & $108.78 \mathrm{ab}$ & $197.08 \mathrm{ab}$
\end{tabular}

Keterangan : Angka yang diikuti oleh huruf yang sama menunjukkan tidak berbeda nyata pada $\operatorname{taraf} \alpha=5 \%$

Hasil penelitian Roli (2013) menyatakan perlakuan dosis pupuk $\mathrm{K}$ pada tanaman jagung hibrida varietas Pertiwi-2, berpengaruh nyata terhadap pertumbuhan tinggi tanaman pada 4 MST, 7 MST dan 8 MST. Dosis pupuk K $100 \mathrm{~kg}$ ha $^{-1}$ memberikan hasil tertinggi terhadap kontrol, dosis pupuk $\mathrm{K} 100 \mathrm{~kg} \mathrm{ha}^{-1}$ tidak berbeda nyata dengan dosis $50 \mathrm{~kg} \mathrm{ha}^{-1}$ dan $75 \mathrm{~kg} \mathrm{ha} \mathrm{ha}^{-1}$, sedangkan dosis $25 \mathrm{~kg} \mathrm{ha}^{-1}$ tidak berbeda nyata dengan kontrol.

Hasil yang sama ditunjukkan pada penelitian Putri (2008), yang menyatakan perlakuan dosis pupuk $\mathrm{K}$ pada tanaman jagung varietas Bisi-16 panen muda, berpengaruh nyata terhadap pertumbuhan tinggi tanaman pada 4 MST, 6 MST dan 8 MST. Hasil penelitian menunjukkan bahwa pupuk $\mathrm{K}$ berpengaruh terhadap pertumbuhan tinggi tanaman. Pada minggu 6 faktor interaksi berpengaruh sangat nyata hal ini dapat dilihat pada Tabel 4.

Tabel 4. Pengaruh interaksi dosis pupuk $\mathrm{KCl}$ dan waktu aplikasi terhadap pertumbuhan tinggi tanaman jagung manis pada 6 MST

\begin{tabular}{|c|c|c|c|}
\hline \multirow{2}{*}{$\begin{array}{l}\text { Dosis } \\
\left(\mathrm{kg} \mathrm{ha}^{-1}\right)\end{array}$} & \multicolumn{3}{|c|}{ Tinggi Tanaman $(\mathrm{cm})$} \\
\hline & Saat Tanam & $\begin{array}{c}\text { Saat Tanam, } \\
4 \text { MST }\end{array}$ & $\begin{array}{c}\text { Saat Tanam, } \\
4 \text { MST, } 7 \text { MST }\end{array}$ \\
\hline$\overline{0}$ & 184.45 bcde & $174.27 \mathrm{e}$ & 185.07 bcde \\
\hline 50 & $189.40 \mathrm{abcd}$ & $202.77 \mathrm{a}$ & $201.53 \mathrm{a}$ \\
\hline 100 & $186.90 \mathrm{bcde}$ & $183.00 \mathrm{cde}$ & $194.50 a b c$ \\
\hline 150 & $198.80 \mathrm{ab}$ & $201.90 \mathrm{a}$ & $179.13 \mathrm{de}$ \\
\hline
\end{tabular}

Keterangan : Angka yang diikuti oleh huruf yang sama menunjukkan tidak berbeda nyata pada $\operatorname{taraf} \alpha=5 \%$

Berdasarkan data Tabel 4 didapatkan pengaruh interaksi antara dosis pupuk $\mathrm{KCl}$ dengan waktu aplikasi, dimana didapatkan hasil terbaik pada interaksi antara dosis $50 \mathrm{~kg} \mathrm{ha}^{-1}$ dengan $2 \mathrm{x}$ aplikasi. Interaksi antara dosis $50 \mathrm{~kg} \mathrm{ha}^{-1}$ dengan $2 \mathrm{x}$ aplikasi tidak berbeda nyata dengan interaksi antara dosis $50 \mathrm{~kg} \mathrm{ha}^{-1}$ dengan $1 \mathrm{x}$ aplikasi, interaksi antara dosis $50 \mathrm{~kg} \mathrm{ha}^{-1}$ dengan $3 \mathrm{x}$ aplikasi, interaksi antara dosis $100 \mathrm{~kg} \mathrm{ha}^{-1}$ dengan $3 \mathrm{x}$ aplikasi, interaksi antara dosis $150 \mathrm{~kg}$ $\mathrm{ha}^{-1}$ dengan 1x aplikasi, dan interaksi antara dosis $150 \mathrm{~kg} \mathrm{ha}^{-1}$ dengan $2 \mathrm{x}$ aplikasi.

Hasil penelitian Roli (2013) menyatakan terdapat interaksi antara dosis pupuk $\mathrm{K}$ dan varietas jagung. Hasil tertinggi didapatkan pada dosis $100 \mathrm{~kg} \mathrm{ha}^{-1}$ pada varietas Pertiwi-2.

Perlakuan waktu aplikasi dan interaksi tidak berpengaruh nyata terhadap diameter batang tanaman jagung manis. Dosis pupuk $\mathrm{KCl}$ berpengaruh sangat nyata terhadap diameter batang tanaman jagung manis. Data pengaruh dosis pupuk terhadap pertumbuhan diameter batang jagung manis dapat dilihat pada Tabel 5 .

Tabel 5. Pengaruh dosis pupuk $\mathrm{KCl}$ terhadap pertumbuhan diameter batang jagung manis

\begin{tabular}{lcccc}
\hline \multirow{2}{*}{ Dosis $\left(\mathrm{kg} \mathrm{ha}^{-1}\right)$} & \multicolumn{4}{l}{ Diameter Batang Jagung Manis $(\mathrm{mm})$} \\
\cline { 2 - 5 } & $2 \mathrm{MST}$ & $3 \mathrm{MST}$ & $4 \mathrm{MST}$ & $5 \mathrm{MST}$ \\
\hline 0 & $4.71 \mathrm{~b}$ & $11.97 \mathrm{~b}$ & $19.12 \mathrm{~b}$ & $23.34 \mathrm{~b}$ \\
50 & $6.46 \mathrm{a}$ & $16.89 \mathrm{a}$ & $23.30 \mathrm{a}$ & $27.95 \mathrm{a}$ \\
100 & $6.62 \mathrm{a}$ & $17.09 \mathrm{a}$ & $23.44 \mathrm{a}$ & $28.09 \mathrm{a}$ \\
150 & $6.96 \mathrm{a}$ & $17.52 \mathrm{a}$ & $24.11 \mathrm{a}$ & $28.96 \mathrm{a}$ \\
\hline
\end{tabular}

Keterangan : Angka yang diikuti oleh huruf yang sama menunjukkan tidak berbeda nyata pada taraf $\alpha=5 \%$

Berdasarkan Tabel 5 didapatkan pertambahan diameter semua perlakuan yang diberi pupuk $\mathrm{KCl}$ lebih baik pertumbuhan 
diameter batang tanaman dibanding tanaman yang tidak mendapat perlakuan pupuk $\mathrm{KCl}$. Aplikasi $\mathrm{KCl}$ dosis $50 \mathrm{~kg} \mathrm{ha}^{-1}$ tidak berbeda nyata dengan dosis $100 \mathrm{~kg} \mathrm{ha}^{-1}$ dan dosis $150 \mathrm{~kg} \mathrm{ha}^{-1}$ pada setiap minggu pengamatan.

Hasil penelitian Roli (2013) menyatakan perlakuan pupuk $\mathrm{K}$ memberikan pengaruh yang nyata terhadap diameter batang jagung varietas Pertiwi-2, NK-33 dan BISI-2 pada 2-8 MST. Dosis $100 \mathrm{~kg} \mathrm{ha}^{-1}$ pada 2, 3, 4, 6, 7 MST memberikan hasil tertinggi, sedangkan pada 5 MST dosis $100 \mathrm{~kg} \mathrm{ha}^{-1}$ memberikan hasil lebih tinggi dari dosis $25 \mathrm{~kg} \cdot \mathrm{ha}^{-1}$ dan dosis $50 \mathrm{~kg} \mathrm{ha}^{-1}$, tetapi tidak berbeda nyata dengan dosis $75 \mathrm{~kg} \mathrm{ha}^{-1}$.

Dosis pupuk $\mathrm{KCl}$ berpengaruh sangat nyata terhadap pertambahan jumlah daun terbuka tanaman jagung manis. Pengaruh dosis pupuk terhadap pertambahan jumlah daun terbuka jagung manis dapat dilihat pada Tabel 6 .

Tabel 6. Pengaruh dosis pupuk $\mathrm{KCl}$ terhadap pertambahan jumlah daun terbuka jagung manis.

\begin{tabular}{lccc}
\hline \multirow{2}{*}{ Dosis $\left(\mathrm{kg} \mathrm{ha}^{-1}\right)$} & \multicolumn{3}{c}{ Jumlah Daun Terbuka Jagung Manis } \\
\cline { 2 - 4 } & $2 \mathrm{MST}$ & $5 \mathrm{MST}$ & $6 \mathrm{MST}$ \\
\hline 0 & $3.59 \mathrm{~b}$ & $12.58 \mathrm{~b}$ & $12.58 \mathrm{~b}$ \\
50 & $4.01 \mathrm{a}$ & $12.81 \mathrm{ab}$ & $12.94 \mathrm{a}$ \\
100 & $4.04 \mathrm{a}$ & $13.08 \mathrm{a}$ & $13.08 \mathrm{a}$ \\
150 & $3.89 \mathrm{ab}$ & $13.10 \mathrm{a}$ & $13.10 \mathrm{a}$ \\
\hline
\end{tabular}

Keterangan : Angka yang diikuti oleh huruf yang sama menunjukkan tidak berbeda nyata pada $\operatorname{taraf} \alpha=5 \%$

Berdasarkan Tabel 6 didapatkan jumlah daun terbuka tanaman jagung manis yang dipengaruhi oleh pemberian pupuk $\mathrm{KCl}$ pada 2 MST, 5 MST, dan 6 MST, didapatkan semua perlakuan yang diberi pupuk $\mathrm{KCl}$ lebih baik pertambahan jumlah daun tanaman dibanding tanaman yang tidak mendapat perlakuan. Dosis $150 \mathrm{~kg} \mathrm{ha}^{-1}$ pada 2 MST dan dosis $50 \mathrm{~kg} \mathrm{ha}^{-1}$ pada 5 MST menghasilkan jumlah daun yang tidak berbeda nyata dengan tanaman yang tidak diberi perlakuan pupuk K.

\section{Produksi Jagung Manis}

Dosis pupuk $\mathrm{KCl}$ berpengaruh sangat nyata terhadap bobot tongkol tanpa kelobot, panjang tongkol, diameter tongkol, dan jumlah baris biji. Dosis pupuk $\mathrm{KCl}$ berpengaruh nyata terhadap bobot tongkol dengan kelobot dan produktivitas jagung manis. Perlakuan waktu aplikasi dan interaksi tidak berpengaruh nyata terhadap peubah-peubah tersebut. Rekapitulasi hasil produksi jagung berdasarkan perlakuan dosis dapat dilihat pada Tabel 7.

Berdasarkan hasil Tabel 7 didapatkan pada semua peubah hasil produksi didapatkan semua sampel yang diberi pupuk $\mathrm{KCl}$ memiliki hasil produksi yang lebih baik dibandingkan dengan peubah yang tidak diberi perlakuan pupuk KCl. Dosis $50 \mathrm{~kg} \mathrm{ha}^{-1}$ pada peubah jumlah baris biji, bobot tongkol dengan kelobot dan produktivitas memiliki hasil yang tidak berbeda nyata dengan tanaman yang tidak diberi pupuk.

Menurut Putri (2008), pemberian kalium dengan dosis $0-200 \mathrm{~kg} \mathrm{ha}^{-1}$ berpengaruh terhadap indeks luas daun, bobot brangkasan dan persen kelayakan jual tanaman jagung muda. Pemberian kalium optimum didapatkan pada dosis $100 \mathrm{~kg} \mathrm{ha}^{-}$ ${ }^{1}$. Menurut Adrie dan Veronica (2005), pemberian kalium pada tanaman jagung manis varietas Super Bee berpengaruh terhadap tinggi tanaman, jumlah tongkol isi per petak dan bobot tongkol segar. Pemberian kalium optimum didapatkan pada dosis $100 \mathrm{~kg} \mathrm{ha}^{-1}$.

\section{Tingkat Kemanisan $\left({ }^{\circ}\right.$ Brix $)$}

Tingkat kemanisan jagung manis diukur secara tidak langsung dengan mengukur nilai Padatan Terlarut Total (PTT). Semakin tinggi nilai PTT diduga rasa manis pada jagung manis semakin tinggi. Pengaruh dosis pupuk $\mathrm{KCl}$ terhadap derajat kemanisan ( ${ }^{\circ}$ brix) dapat dilihat pada Tabel 8 .

Tabel 8. Pengaruh Interaksi dosis pupuk $\mathrm{KCl}$ dan waktu aplikasi terhadap derajat kemanisan

\begin{tabular}{lccc}
\hline \multirow{2}{*}{$\begin{array}{l}\text { Dosis } \\
\left(\mathrm{kg} \mathrm{ha}^{-1}\right)\end{array}$} & \multicolumn{3}{c}{ Tinggi Tanaman $(\mathrm{cm})$} \\
\cline { 2 - 4 } & Saat Tanam & $\begin{array}{c}\text { Saat Tanam, } \\
\text { 4 MST }\end{array}$ & $\begin{array}{c}\text { Saat Tanam, } \\
\text { 4 MST, 7 MST }\end{array}$ \\
\hline 0 & $11.43 \mathrm{~h}$ & $14.43 \mathrm{~h}$ & $14.43 \mathrm{~h}$ \\
50 & $13.20 \mathrm{~g}$ & $15.82 \mathrm{cda}$ & $16.33 \mathrm{bc}$ \\
100 & $14.32 \mathrm{f}$ & $15.33 \mathrm{de}$ & $16.73 \mathrm{abc}$ \\
150 & $14.82 \mathrm{ef}$ & $16.12 \mathrm{c}$ & $19.88 \mathrm{a}$ \\
\hline
\end{tabular}

Keterangan : Angka yang diikuti oleh huruf yang sama menunjukkan tidak berbeda nyata pada taraf $\alpha=5 \%$

Tabel 7. Rekapitulasi hasil pengaruh dosis pupuk $\mathrm{KCl}$ terhadap hasil produksi jagung manis

\begin{tabular}{lcccccc}
\hline Dosis $\left(\mathrm{kg} \mathrm{ha}^{-1}\right)$ & $\begin{array}{c}\text { Panjang } \\
\text { Tongkol }(\mathrm{cm})\end{array}$ & $\begin{array}{c}\text { Diameter } \\
\text { Tongkol }(\mathrm{mm})\end{array}$ & $\begin{array}{c}\text { Jumlah Baris } \\
\text { Biji }\end{array}$ & $\begin{array}{c}\text { Bobot Tongkol } \\
\text { dengan Kelobot }(\mathrm{g})\end{array}$ & $\begin{array}{c}\text { Bobot Tonpa Kelobot }(\mathrm{g}) \\
\text { tanpal }\end{array}$ & $\begin{array}{c}\text { Dugaan Produktivitas } \\
(\text { ton ha }\end{array}$ \\
\hline 0 & $15.45 \mathrm{~b}$ & $40.44 \mathrm{~b}$ & $15.91 \mathrm{~b}$ & $318.43 \mathrm{~b}$ & $230.31 \mathrm{~b}$ & $17.44 \mathrm{~b}$ \\
50 & $16.59 \mathrm{a}$ & $43.02 \mathrm{a}$ & $16.36 \mathrm{ab}$ & $341.80 \mathrm{ab}$ & $260.33 \mathrm{a}$ & $18.67 \mathrm{ab}$ \\
100 & $17.03 \mathrm{a}$ & $43.32 \mathrm{a}$ & $16.53 \mathrm{a}$ & $356.42 \mathrm{a}$ & $264.57 \mathrm{a}$ & $19.63 \mathrm{a}$ \\
150 & $17.18 \mathrm{a}$ & $43.48 \mathrm{a}$ & $16.76 \mathrm{a}$ & $362.73 \mathrm{a}$ & $270.17 \mathrm{a}$ & $19.74 \mathrm{a}$ \\
\hline
\end{tabular}

Keterangan : Angka yang diikuti oleh huruf yang sama menunjukkan tidak berbeda nyata pada taraf $\alpha=5 \%$ 
Berdasarkan data Tabel 8 didapatkan interaksi antara dosis 150 dengan waktu aplikasi saat tanam, 4 MST, 7 MST memiliki hasil terbaik dengan hasil $19.88^{\circ}$ brix. Makin tinggi dosis $\mathrm{K}$ makin tinggi nilai PTT sehingga diduga dosis $\mathrm{K}$ meningkatkan rasa manis. Pemupukan dosis Kalium dan waktu aplikasi sebanyak 3 kali menghasilkan nilai PTT nyata tertinggi sehingga diduga meningkatkan rasa manis.

Hasil penelitian Ardani (2010) menyatakan bahwa pemberian pupuk Kalium $1.6 \mathrm{~g} \mathrm{~K}_{2} \mathrm{O}$ per tanaman berpengaruh paling baik pada parameter tingkat kemanisan buah jagung manis sebesar 14.25 orix. Pupuk Kalium $16 \mathrm{~g}$ $\mathrm{K}_{2} \mathrm{O}$ per tanaman setara dengan $80 \mathrm{~kg} \mathrm{~K}_{2} \mathrm{O}$ ha $^{-1}$ (dengan populasi 50.000 tanaman $\mathrm{ha}^{-1}$ ) atau setara dengan $133 \mathrm{~kg} \mathrm{ha}^{-1} \mathrm{KCl}$.

\section{KESIMPULAN}

Dosis pupuk $\mathrm{KCl}$ berpengaruh nyata dan sangat nyata pada peubah tinggi tanaman, diameter batang, jumlah daun, kecuali pada tinggi tanaman umur 3 MST, diameter batang umur 6 MST dan jumlah daun umur 3 dan 4 MST. Dosis pupuk $\mathrm{KCl}$ berpengaruh nyata dan sangat nyata terhadap semua peubah hasil. Waktu aplikasi tidak berpengaruh nyata pada semua peubah kecuali tingkat kemanisan jagung manis. Interaksi tidak berpengaruh nyata pada semua peubah kecuali pada tinggi umur 6 MST dan tingkat kemanisan. Semua perlakuan yang diberi pupuk $\mathrm{KCl}$ lebih baik hasilnya dibanding tanaman yang tidak mendapat perlakuan Berdasarkan hasil penelitian, pertumbuhan dan produksi jagung manis pada dosis $\mathrm{KCl} 50 \mathrm{~kg} \mathrm{ha}^{-1}$ tidak berbeda nyata dengan dosis $100 \mathrm{~kg} \mathrm{ha}^{-1}$ dan dosis $150 \mathrm{~kg} \mathrm{ha}^{-1}$. Tingkat kemanisan jagung manis tertinggi didapatkan pada interaksi dosis $150 \mathrm{~kg} \mathrm{ha}^{-1}$ dengan waktu aplikasi 3 kali.

\section{DAFTAR PUSTAKA}

Adrie, H.S., K. Veronica. 2005. Studi pemupukan kalium terhadap pertumbuhan dan hasil jagung manis varietas Super Bee. [Skripsi]. Universitas Muria. Kudus.

Afandie, R., W.Y. Nasih. 2002. Ilmu Kesuburan Tanah. Kanisius. Yogyakarta.

Agusman, N.R. 2000. Pengaruh taraf pemupukan kalium pada berbagai status kalium tanah terhadap produksi pipilan biji kering jagung varietas hibrida Pioneer-5 pada tanah latosol (oksik dystropept) Darmaga. [Skripsi]. Institut Pertanian Bogor. Bogor.
Ardani, M. 2010. Aplikasi dosis dan waktu pemberian pupuk kalium $\left(\mathrm{K}_{2} \mathrm{O}\right)$ terhadap produksi dan tingkat kemanisan jagung Manis (Zea mays saccharata Sturt). [Skripsi]. Universitas Moch. Sroedji. Jember.

[BPS] Badan Pusat Statistik. 2015. Indikator Pertanian Agricultural Indicator 2014/2015. https://www.bps.go.id/website/pdf_publikas i/Indikator-pertanian -2014-2015.rev.pdf. [23 Juni 2016].

[BPS SulSel] Badan Pusat Statistik Sulawesi Selatan. Luas Panen dan Produksi Palawija menurut Kabupaten/Kota di Provinsi Sulawesi Selatan. 2013. http://sulsel.bps. go.id/link Table Dinamis/view/id/16. [23 Juni 2016].

Forth, H.D. 1978. Dasar Dasar Ilmu Tanah. Diterjemahkan oleh Soenartono Adisoemarto. Gadjah Mada University Press. Yogyakarta.

Joe C., H. Mae-wan. 2005. Hybrid Seed. Sience in Society Archieve. United Kingdom.

Koswara, J. 1986. Budidaya Jagung Manis. Yasaguna. Jakarta.

Marsono, Sigit. 2001. Pupuk Akar. Penebar Swadaya. Jakarta.

Mattjik, A.A., I.M. Sumertajaya. 2013. Perancangan Percobaan dengan Aplikasi SAS dan Minitab. IPB Press. Bogor.

Moentono, M.D. 1988. Improving corn quality through breeding and cultural practices. J. Indonesian Agricultural Research and Development. 10 (4): 105-109.

Novizan. 2002. Petunjuk Pemupukan yang Efektif. Agromedia Pustaka. Tangerang.

Nugroho, R.A.P. 2015. Evaluasi daya gabung dan heterosis jagung manis (Zea mays L. var. saccharata). [Skripsi]. Institut Pertanian Bogor.bogor

Olson, R.A., D.H. Sander. 1988. Corn Production. In Monograph Agronomy Corn and Corn Improvement. Wisconsin.

Purwono, R. Hartono. 2008. Bertanam Jagung Unggul. Penebar Swadaya. Jakarta.

Putri, H.A. 2011. Pengaruh pemberian beberapa konsentrasi pupuk organik cair lengkap (POCL) Bio Sugih terhadap pertumbuhan dan hasil tanaman jagung manis (Zea mays saccharata Sturt). [Skripsi]. Universitas Andalas. Padang. 
Putri, J.D. 2008. Pengaruh kalium terhadap pertumbuhan, produksi dan kualitas jagung muda. [Skripsi]. Institut Pertanian Bogor. Bogor.

Rinsema, W.T. 1983. Pupuk dan Cara Pemupukan. Bharatara Karya. Jakarta.

Rohlini. 1982. Studi korelasi berbagai metode ekstraksi kalium dapat ditukarkan dengan kandungan kalium tanaman jagung (Zea mays) dalam hubungannya dengan pemupukan alium pada tanah-tanah dari enam lokasi di Kabupaten Bogor. [Tesis]. Institut Pertanian Bogor. Bogor.

Roli, I. 2013. Respon beberapa varietas tanaman jagung (Zea mays L.) hibrida pada berbagai dosis pupuk kalium terhadap pertumbuhan dan hasil beberapa varietas tanaman jagung (Zea mays L.) hibrida. [Skripsi]. Universitas Gorontalo. Gorontalo.

Rubatzky, V.E., M. Yamaguchi. 1995. World Vegetables: Principle, Production, and Nutritive Value. Second Edition. Aspen Publishers Inc. Maryland.

Ruhnayat, A. 1995. Peranan unsur hara Kalium dalam meningkatkan pertumbuhan hasil dan daya tahan tanaman rempah dan obat. Jurnal Litbang Pertanian 14(1) : 10-15.
Sarwono, H. 2003. Ilmu Tanah. Akademika Pressindo. Jakarta.

Sirappa, M.P., N. Razak. 2010. Peningkatan produktivitas jagung melalui pemberian pupuk N, P, K dan pupuk kompos pada lahan kering di Maluku. hal 277-286. Prosiding Pekan Serealia Nasional. Meningkatkan Peran Serealia menuju Swasembada Pangan Berkelanjutan. Balit Sereal Litbang Kementrian Pertanian, Maros, 27-28 Juli 2010.

Suarni, M. Yasin. 2015. Jagung sebagai Sumber Pangan Fungsional. Pusat Penelitian dan Pengembangan Tanaman Pangan. Bogor.

Sugito, J., R. Palungkun, E. Liatyowati. 1991. Sweet Corn Baby Corn. Penebar Swadaya. Jakarta.

Syukur, M., A. Rifianto. 2013. Jagung Manis. Penebar Swadaya. Jakarta.

Taiz, L., E. Zeiger. 2002. Plant Physiology. 3rd Edition. Sinauer Associates. Sunderland.

Thompson, H.C., W.C. Kelly. 1957. Vegetable Crops. Mcgraw-Hill Book Co. Inc. New York.

Tim Penulis PS. 2002. Sweet Corn Baby Corn. Penebar Swadaya. Jakarta. 